\title{
Roe deer Capreolus capreolus as an accumulative bioindicator of heavy metals in Slovenia
}

\author{
Boštjan Pokorny
}

Pokorny, B. 2000. Roe deer Capreolus capreolus as an accumulative bioindicator of heavy metals in Slovenia. - Web Ecol. 1: 54-62.

\begin{abstract}
Roe deer Capreolus capreolus has often been mentioned in the literature as a good bioindicator of environmental pollution. To find out the levels of heavy metals $(\mathrm{Cd}, \mathrm{Pb}, \mathrm{Hg}$, As, $\mathrm{Zn}$ ) in roe deer tissues, this research project was begun near metallurgic and electricity generating centres of Slovenia in 1997. The results of the first sampling year reveal that metal burdens are the highest in the Koroška region, an industrial area in the northern part of Slovenia with a centuries-old tradition of mining and processing of lead ore. Levels (expressed on a wet weight basis) of Cd $(2.91 \pm 2.92,7.13 \pm 4.43$ and $22.7 \pm 8.92$ $\mathrm{mg} \mathrm{kg}^{-1}$ for fawns, yearlings and adults, respectively), As $\left(0.23 \pm 0.03 \mathrm{mg} \mathrm{kg}^{-1}\right)$ and $\mathrm{Zn}$ $\left(47.1 \pm 8.26 \mathrm{mg} \mathrm{kg}^{-1}\right)$ in kidneys as well as levels of $\mathrm{Pb}\left(0.71 \pm 0.65 \mathrm{mg} \mathrm{kg}^{-1}\right)$ in liver of animals shot in the Koroška region significantly exceed the levels measured in other Slovenian regions. On the contrary, metal levels in viscera of roe deer from the Šalek Valley (where the major Slovene power plant of Šoštanj is located) are low (0.14 \pm $0.01,38.2 \pm 4.39$ and $0.02 \pm 0.03 \mathrm{mg} \mathrm{kg}^{-1}$ for As, $\mathrm{Zn}$ and $\mathrm{Hg}$ in kidney; $0.21 \pm 0.04$ $\mathrm{mg} \mathrm{kg}^{-1}$ for $\mathrm{Pb}$ in liver, respectively). Relatively high levels of $\mathrm{Hg}\left(0.23 \pm 0.09 \mathrm{mg} \mathrm{kg}^{-1}\right.$; six- to tenfold higher compared to other areas of interest) in kidneys and $\mathrm{Pb}(0.55 \pm$ $0.13 \mathrm{mg} \mathrm{kg}^{-1}$ ) in liver of animals shot in the control area of the Triglav National Park, which represents the area without any local emission sources, demonstrate the possibility that animals are being exposed to contaminants that we would not have expected from other data. Consequently, the value of roe deer as an accumulative bioindicator of environmental pollution with heavy metals is clearly confirmed.
\end{abstract}

\section{B. Pokorny (bostjan.pokorny@erico.si),ERICo Velenje, Ecological Research and Industrial} Co-operation, Koroška 58, 3320 Velenje, Slovenia.

Pollution of the environment can be determined by means of biological methods with the help of bioindicators - organisms which give informations on the quality of their environment. Biomonitoring has many advantages over monitoring of non biological materials, such as great availability, low costs, retrospection, no servicing, consideration of synergistic (antagonistic) effects and biological relevance (Wittig 1993). Plant species are most often used for bioindicative purposes. Nevertheless, many wildlife species can also be used as bioindicators of environmental condi- tions (e.g. Arndt et al. 1987). Animals as accumulative monitors of pollution by heavy metals (which belong to the group of the most dangerous inorganic toxic substances) have some advantages over plants, such as arearelated results and comparability to man (Wittig 1993).

Since it fulfils numerous criteria (e.g. widely geographic distribution, relatively small home range, territorial living and browsing nutrition strategy, huge availability of basic data, relatively simple sampling procedure) roe deer Capreolus capreolus has been often mentioned in the literature as 
a good (e.g. Grodzinska et al. 1983, Tataruch 1991, Findo et al. 1993, Straub and Kreimes 1995, Gnamuš and Horvat 1999) or even excellent (Wren 1986) bioindicator of heavy metal burdens of the environment. As well as hard body-parts such as teeth (e.g. Mankovska 1980) and antlers (e.g. Sawicka-Kapusta 1979, Kardell and Källman 1985, Samiullah and Jones 1991, Chyla et al. 1996), soft tissues (e.g. Hecht et al. 1984, Müller 1985, Frank 1986, Chudik and Mankovska 1990, Tataruch 1991, Findo et al. 1993, Pokorny and Ribarič-Lasnik 2000) are the most often used accumulative organs.

We compared levels of $\mathrm{Cd}, \mathrm{Pb}, \mathrm{Hg}$, As and $\mathrm{Zn}$ in viscera of roe deer shot in the vicinity of Slovenian metallurgical and electricity generating centres, like the Koroška region (an industrial area with a centuries-old tradition of mining and processing of lead and zinc ore), the Šalek Valley (where the major Slovene power plant of Šoštanj is located) and the Zasavje region (where again a large power plant as well as a cement factory are operated). The Pokljuka Plateau situated in the Triglav National Park was included in the study as a control area without any local emission sources. A brief summary of the comparison (Pokorny and Ribarič-Lasnik 2000) with a similar research performed in the Koroška region in 1986 (Osrajnik 1990) is also given herein. It is of particular importance because in the meantime the primary manufacture of lead ore was stopped at the lead smelter at Žerjav. Resulting spatial and temporal differences in heavy metal burdens in roe deer tissues could reveal the importance of the species as a bioindicator.

\section{Material and methods}

Kidneys and livers of 188 roe deer $(79$ from the Šalek Valley, 43 from the Koroška region, 32 from the Zasavje region and 21 from the Pokljuka Plateau) were collected in the period from 1 June to 31 December 1997 by local hunter authorities. All animals were shot with legal permission. Each animal was assigned basic data such as sex, body weight, the date and shooting location. Age was estimated subsequently by an experienced hunter, using method of mandible tooth wear (Simonič 1976). Age classes were defined as fawns, yearlings, young adults (2-4 yr), middle-aged adults (5-7 yr) and elderly adults ( $>7 \mathrm{yr})$, respectively. The age estimation using tooth wear criteria is precise only in the case of fawns and yearlings, which have tricuspid deciduous third premolar. Although the error in the age estimation of adults is generally not high, averaging $\pm 1.02 \mathrm{yr}$ (Hewison et al. 1999), considerable errors could occur for certain specimens due to variation in rates of tooth wear among population and individuals as well as because of observer bias. To reduce that kind of error, all three adult subclasses were pooled together into one adult class (animals two or more years old) before the processing of data. This amalgamation is reasonable since previous statistical analysis did not reveal differences in levels of any single metal among adult subclasses (Pokorny 1999a).

After dissection tissues were packed separately, frozen and sent to the laboratory at ERICo Velenje, where they were stored at $-18^{\circ} \mathrm{C}$ till the analyses were performed. Tis-

Table 1. Levels of Cd ( $\mathrm{mg} \mathrm{kg}^{-1}$ wet weight) in kidneys of roe deer shot in some Slovenian regions in 1997 . The arithmetic means $(\overline{\mathrm{a}})$ with the $95 \%$ confidence intervals, coefficient of variation (CV \%) and range (Min, Max) are given.

\begin{tabular}{|c|c|c|c|c|c|}
\hline Region & $\mathrm{n}$ & $\overline{\mathrm{a}} \pm \mathrm{t}_{0.05} * \mathrm{SE}$ & $\mathrm{CV} \%$ & Min & Max \\
\hline \multicolumn{6}{|l|}{ Fawns } \\
\hline Šalek Valley & 14 & $0.52 \pm 0.25$ & 22 & 0.07 & 1.71 \\
\hline Koroška region & 3 & $2.92 \pm 2.92$ & 51 & 0.45 & 5.60 \\
\hline Zasavje region & 2 & $0.21 \pm 1.21$ & 46 & 0.11 & 0.30 \\
\hline Pokljuka Plateau & 5 & $1.94 \pm 0.61$ & 11 & 1.30 & 2.63 \\
\hline \multicolumn{6}{|l|}{ Yearlings } \\
\hline Šalek Valley & 29 & $4.35 \pm 1.87$ & 21 & 0.15 & 24.6 \\
\hline Koroška region & 16 & $7.13 \pm 4.43$ & 29 & 1.00 & 30.7 \\
\hline Zasavje region & 5 & $1.59 \pm 0.80$ & 18 & 0.55 & 2.24 \\
\hline Pokljuka Plateau & 6 & $2.72 \pm 1.11$ & 16 & 1.53 & 4.10 \\
\hline \multicolumn{6}{|l|}{ Adults } \\
\hline Šalek Valley & 32 & $8.27 \pm 2.82$ & 17 & 1.17 & 43.7 \\
\hline Koroška region & 22 & $22.7 \pm 8.92$ & 19 & 2.31 & 76.0 \\
\hline Zasavje region & 21 & $9.95 \pm 3.57$ & 17 & 1.57 & 30.1 \\
\hline Pokljuka Plateau & 9 & $4.16 \pm 0.99$ & 10 & 1.94 & 5.58 \\
\hline
\end{tabular}


sues were homogenised with Büchi-Mixer B-400 with a ceramic knife. A CEM MSP 1000 microwave digestion system was used for a wet digestion of samples. Tissue samples (1.4-1.5 g, wet weight) were weighed to $\pm 0.1 \mathrm{mg}$ into microwave digestion vessels to which $7 \mathrm{ml}$ of conc. $\mathrm{HNO}_{3}$ and $1 \mathrm{ml}$ of $\mathrm{H}_{2} \mathrm{O}_{2}$ were added. Element contents were determined using a Perkin Elmer SIMAA 6000 atomic absorption spectrometer. The electrothermal technique was used for the determination of $\mathrm{Pb}$ and $\mathrm{Cd}$, the flame technique for the determination of $\mathrm{Zn}$, while the hydride technique was used for the determination of $\mathrm{Hg}$ and $\mathrm{As} . \mathrm{Pb}$, $\mathrm{Cd}, \mathrm{Zn}, \mathrm{Hg}$ and As were measured with hollow cathode lamps at $283.3 \mathrm{~nm}, 228.8 \mathrm{~nm}, 213.9 \mathrm{~nm}, 253.7 \mathrm{~nm}$ and $193.7 \mathrm{~nm}$, respectively. Standard reference material (Bovine liver BCR 185) was used for analytical quality assurance. The agreement for $\mathrm{Pb}$ (BCR 185: $501 \pm 27 \mathrm{ng} \mathrm{g}^{-1}$ ) was 98-103\%, for Cd (BCR 185: $298 \pm 25 \mathrm{ng} \mathrm{g}^{-1}$ ) 94$108 \%$, for Zn (BCR 185: $142 \pm 3 \mathrm{ng} \mathrm{g}^{-1}$ ) 97-105\%, for $\mathrm{Hg}$ (BCR 185: $44 \pm 3 \mathrm{ng} \mathrm{g}^{-1}$ ) $90-110 \%$ and for As (BCR 185: $\left.24 \pm 3 \mathrm{ng} \mathrm{g}^{-1}\right)$ 92-110\%.

Student t-test and analysis of variance (ANOVA) with calculating lowest significant difference (LSD; $\mathrm{LSD}_{\mathrm{a}-\mathrm{b}}=$ $\mathrm{t}_{\alpha / 2}{ }^{*} \operatorname{se} \sqrt{ }\left(1 / \mathrm{n}_{\mathrm{a}}+1 / \mathrm{n}_{\mathrm{b}}\right)$; Kotar 1977) were used for statistical evaluation of the data. Spatial and temporal comparisons were made only for the organs where the major accumulation of a particular element takes place (kidney for $\mathrm{Cd}$, $\mathrm{Hg}, \mathrm{Zn}$ and As; liver for $\mathrm{Pb}$ ). All results are given as $\mathrm{mg}$ $\mathrm{kg}^{-1}$ on a wet weight basis.

\section{Results}

Levels of $\mathrm{Cd}, \mathrm{Pb}, \mathrm{Hg}$, As and $\mathrm{Zn}$ in roe deer tissues from all areas are presented in Tables 1, 2, 3, 4 and 5, respectively. To make the tables more explicit, only results for those organs where the major accumulation of a particular element takes place are given. Levels of $\mathrm{Cd}$ are presented separately for different age classes (fawns, yearlings and adult animals) because of increasing Cd levels in roe deer tissues with the age of the animal analysed (e.g. Tataruch 1991, Doganoc and Šinigoj-Gačnik 1995). Discussion for Cd is limited to adults only due to a relatively small sample size for fawns and yearlings in all areas.

Statistical analyses (t-test inside areas) showed no sexrelated differences in accumulation of any single element (example for Cd in the Šalek Valley: $\mathrm{t}=0.19_{[12]}, 0.11_{[27]}$ and $0.71_{[17]}$ for fawns, yearlings and young adults, respectively), what is consistent with some previous studies (e.g. Woolf et al. 1982, Müller 1985). Moreover, the ANOVA procedure among age classes showed no age-related differences in accumulation of any single element except $\mathrm{Cd}$, for which concentrations in the viscera significantly increase with the age class (for example, $\mathrm{F}_{[2,38]}=5.46 ; \mathrm{p}<0.01$ and $\mathrm{F}_{[2.72]}=8.79 ; \mathrm{p}<0.001$ for the Koroška region and the Šalek Valley, respectively). So, individual burdens of all toxic elements can be pooled together for both sexes as well as for all age classes (this last amalgamation being true for all elements but $\mathrm{Cd}$ ). These simplifications make the species very suitable for the bioindicative purposes.

\section{Discussion}

Differences in levels of heavy metals in roe deer tissues are statistically significant among areas of interest (ANOVA, Table 6). The burdens are the highest in the Koroška region, an industrial area in the northern part of Slovenia with a centuries-old tradition of mining and processing of lead and zinc ore (Tables 1-5), where levels of all toxic elements but $\mathrm{Hg}$ are significantly higher in comparison with other areas (Table 6). Furthermore, Cd levels in kidneys of adult animals shot in the Koroška region are among the highest levels ever measured in viscera of European roe deer as well as in its near relative white-tailed deer Odocoileus virginianus (Table 7). Nevertheless, the Cd levels are well below the concentrations dangerous for the health of mammals, which are defined as $100-300 \mathrm{mg} \mathrm{kg}^{-1}$ of wet weight (for review, see Cooke and Johnson 1996, Pascoe et al. 1996).

One previous study (Pokorny and Ribarič-Lasnik 2000; see also Osrajnik 1990) revealed that the average Cd levels in kidneys of yearlings shot in the Koroška region have increased 3.5-fold since 1986 (from $2.05 \mathrm{mg} \mathrm{kg}^{-1}$ to $\left.7.13 \pm 4.43 \mathrm{mg} \mathrm{kg}^{-1} ; \mathrm{p}<0.05\right)$ and in kidneys of adults by more than tenfold (from $2.21 \mathrm{mg} \mathrm{kg}^{-1}$ to $22.7 \pm 8.92 \mathrm{mg}$ $\left.\mathrm{kg}^{-1} ; \mathrm{p}<0.001\right)$. Exact causes for that trend are unknown, but increasing emissions of $\mathrm{Cd}$ into the environment (industry, agriculture etc.) and increasing acidification of soil caused by acid rain (influence on the bioavaibility of $\mathrm{Cd}$ ) should be mentioned among them. In contrast to $\mathrm{Cd}$,

Table 2. Levels of $\mathrm{Pb}\left(\mathrm{mg} \mathrm{kg}^{-1}\right.$ wet weight) in liver of roe deer shot in some Slovenian regions in 1997. The arithmetic means ( $\left.\overline{\mathrm{a}}\right)$ with the $95 \%$ confidence intervals, coefficient of variation (CV \%) and range (Min, Max) are given.

\begin{tabular}{llllll}
\hline Region & $\mathrm{n}$ & $\overline{\mathrm{a}} \pm \mathrm{t}_{0.05}{ }^{*} \mathrm{SE}$ & CV \% & Min & Max \\
\hline Šalek Valley & 71 & $0.21 \pm 0.04$ & 10 & $<0.05$ & 0.82 \\
Koroška region & 29 & $0.71 \pm 0.65$ & 44 & $<0.05$ & $9.30^{*}$ \\
Zasavje region & 26 & $0.11 \pm 0.05$ & 22 & $<0.05$ & 0.57 \\
Pokljuka Plateau & 13 & $0.55 \pm 0.13$ & 11 & $<0.05$ & 0.92 \\
\hline
\end{tabular}

* Secondary contamination by lead bullet. Liver direct hit by the bullet were not included in the analyses. 
Table 3. Levels of $\mathrm{Hg}$ ( $\mathrm{mg} \mathrm{kg}^{-1}$ wet weight) in kidneys of roe deer shot in some Slovenian regions in 1997. The arithmetic means $(\overline{\mathrm{a}})$ with the $95 \%$ confidence intervals, coefficient of variation (CV \%) and range (Min, Max) are given.

\begin{tabular}{llllll}
\hline Region & $\mathrm{n}$ & $\overline{\mathrm{a}} \pm \mathrm{t}_{0.05}{ }^{*} \mathrm{SE}$ & CV \% & Min & Max \\
\hline Šalek Valley & 75 & $0.02 \pm 0.01$ & 19 & $<0.01$ & 0.21 \\
Koroška region & 41 & $0.04 \pm 0.01$ & 16 & $<0.01$ & 0.16 \\
Zasavje region & 28 & $0.03 \pm 0.01$ & 19 & $<0.01$ & 0.12 \\
Pokljuka Plateau & 20 & $0.23 \pm 0.10$ & 20 & $<0.01$ & 0.69 \\
\hline
\end{tabular}

Table 4. Levels of As ( $\mathrm{mg} \mathrm{kg}^{-1}$ wet weight) in kidneys of roe deer shot in some Slovenian regions in 1997. The arithmetic means ( $\left.\overline{\mathrm{a}}\right)$ with the $95 \%$ confidence intervals, coefficient of variation (CV\%) and range (Min, Max) are given.

\begin{tabular}{llllrl}
\hline Region & $\mathrm{n}$ & $\overline{\mathrm{a}} \pm \mathrm{t}_{0.05}{ }^{*} \mathrm{SE}$ & $\mathrm{CV} \%$ & Min & Max \\
\hline Šalek Valley & 75 & $0.14 \pm 0.01$ & 4 & $<0.02$ & 0.25 \\
Koroška region & 41 & $0.23 \pm 0.03$ & 6 & 0.17 & 0.43 \\
Zasavje region & 28 & $0.20 \pm 0.03$ & 7 & 0.14 & 0.42 \\
Pokljuka Plateau & 20 & $0.20 \pm 0.01$ & 3 & 0.16 & 0.24 \\
\hline
\end{tabular}

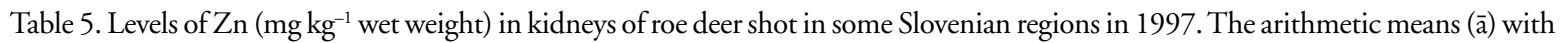
the $95 \%$ confidence intervals, coefficient of variation (CV \%) and range (Min, Max) are given.

\begin{tabular}{lccccc}
\hline Area of interest & $\mathrm{n}$ & $\overline{\mathrm{a}} \pm \mathrm{t}_{0.05}{ }^{*} \mathrm{SE}$ & CV \% & Min & Max \\
\hline Šalek Valley & 75 & $38.2 \pm 4.39$ & 6 & 4.62 & 93.2 \\
Koroška region & 41 & $47.1 \pm 8.26$ & 9 & 8.27 & 144 \\
Zasavje region & 28 & $38.6 \pm 6.26$ & 8 & 9.38 & 83.8 \\
Pokljuka Plateau & 20 & $28.6 \pm 2.18$ & 4 & 22.2 & 38.9 \\
\hline
\end{tabular}

which has a retention time over $10 \mathrm{yr}$, the half-time for $\mathrm{Pb}$ in soft organs of mammals is measured in weeks (Ma 1996). Accordingly, Pb levels in viscera are indicators of the present exposure of animals, while the Cd levels are indicators of long-term exposure. Considering some European trends in heavy metal burdens in deer tissues - a decrease of $\mathrm{Pb}$ levels and an increase of Cd levels in last decade (Niemi et al. 1993 for moose Alces alces from Finland; Swiergosz et al. 1993 for red deer Cervus elaphus from Poland), it is not surprisingly that the average $\mathrm{Pb}$ levels in roe deer tissues from the Koroška region have decreased since 1986 (Pokorny and Ribarič-Lasnik 2000, see also Osrajnik 1990): from 1.72 to $0.04 \pm 0.01 \mathrm{mg} \mathrm{kg}^{-1}(\mathrm{p}<0.001)$ in kidneys and from 1.15 to $0.71 \pm 0.65 \mathrm{mg} \mathrm{kg}^{-1}$ ( $\left.\mathrm{p}>0.05\right)$ in liver. The reduction of $\mathrm{Pb}$ emissions (the lead smelter at Žerjav stopped primary manufacture of lead ore in 1990) and the low bioavailability of the element (although soils are still heavily contaminated with $\mathrm{Pb}$ plants are unable to accumulate it; Grčman et al. 1999) are doubtless the main causes for the decline of $\mathrm{Pb}$ levels in roe deer tissues. The similar conclusion was made also for decreasing $\mathrm{Pb}$ concentrations in blood of dairy cows in the vicinity of the lead smelter in the Koroška region (Zadnik and Jazbec 1996). However, because the unleaded petrol was introduced in Slovenia in the early nineties as well, the lead isotope ratios (see Åberg et al. 1999) should be used to draw a clear distinction between efficiency of both environmental protective measures.

Contrary to our expectations, the heavy metal burdens in the tissues of roe deer shot in the vicinity of the major Slovene power plant of Šoštanj are relatively low (Tables 1$6)$, although the power plant had emitted huge amounts of toxic elements (annually emissions up to $134 \mathrm{t}, 122 \mathrm{t}, 6 \mathrm{t}$ and $0.6 \mathrm{t}$ for $\mathrm{Pb}, \mathrm{Zn}, \mathrm{As}$ and $\mathrm{Hg}$, respectively; Stropnik et al. 1994) before the emission control was built in 1995 . Comparing other areas of interest, levels of As in the Šalek Valley are significantly lower ( $\mathrm{p}<0.001$ for all areas), while for other elements burdens are lower in comparison with the Koroška region $(\mathrm{p}<0.001, \mathrm{p}<0.01$ and $\mathrm{p}<0.05$ for $\mathrm{Cd}$, $\mathrm{Pb}$ and $\mathrm{Zn}$, respectively) as well as with the Pokljuka Plateau in the case of $\mathrm{Hg}(\mathrm{p}<0.001)$. A previous study (Pokorny 1999a) showed also significantly lower burdens of $\mathrm{Cr}$, $\mathrm{Ni}$ and $\mathrm{Cu}$ in spleens of roe deer shot in the Šalek Valley in comparison with the Zasavje and the Koroška region. Accordingly, the Šoštanj Thermal Power Plant has evidently reduced its own negative impact on the environment since the cleaning device was built. The conclusion is consistent with the study (Ribarič-Lasnik et al. 1999) considering some other pollutants, such as sulphur dioxide.

The Triglav National Park was included in the study as a control area without any local emission sources. Nevertheless, the average $\mathrm{Hg}$ levels in kidneys of roe deer shot at 
Table 6. Statistical comparison among areas (ANOVA; differences between two areas were determined by calculation of LSD, which are presented herein; the actual differences in arithmetic means for selected element between two areas are given in parenthesis; for $\mathrm{n}$ see Tables 1-5).

$\begin{array}{lll}\text { Šalek Valley } & \text { Zasavje region } & \text { Pokljuka Plateau } \\ \text { LSD with } \mathrm{P}^{1} & {\text { LSD with } \mathrm{P}^{1}}^{1} & {\text { LSD with } \mathrm{P}^{1}}^{1}\end{array}$

$$
\mathrm{Cd}: \mathrm{F}_{[3,80]}=8.31, \mathrm{p}<0.001
$$

Koroška r.

Šalek V.

Zasavje r.

Koroška r.

Šalek V.

Zasavje r.

Koroška r.

Šalek V.

Zasavje r.

Koroška r.

Šalek V.

Zasavje r.

Koroška r.

Šalek V.

Zasavje r.

\author{
$11.4(14.5)^{* * *}$ \\ I
}

I

Pb: $\mathrm{F}_{[3,135]}=3.73, \mathrm{p}<0.05$

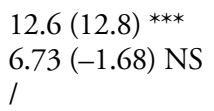

$16.3(18.6)$ ***

9.05 (4.11) NS

$9.56(5.79) \mathrm{NS}$

$0.52(0.16) \mathrm{NS}$

$0.48(-0.34) \mathrm{NS}$

$0.53(-0.44) \mathrm{NS}$

As: $\mathrm{F}_{[3,160]}=49.97, \mathrm{p}<0.001$

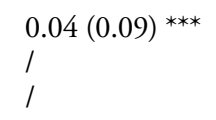

Hg: $\mathrm{F}_{[3,160]}=40.10, \mathrm{p}<0.001$

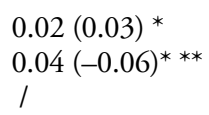
$0.05(-0.06)^{* * *}$ $0.03(0.00) \mathrm{NS}$

Note: ${ }^{1}$ LSD: lowest significant difference (actual difference "line - column" is given in parenthesis); NS: difference is not significant; *: $\mathrm{p}<0.05 ;^{* *}: \mathrm{p}<0.01 ;{ }^{* * *}: \mathrm{p}<0.001$.

Pokljuka Plateau are six- to ten times higher (exhibiting $\mathrm{p}<0.001$ with all areas) compared with near the metallurgical and electricity generating centres of Slovenia. Moreover, $>70 \%$ of kidneys from Pokljuka Plateau exceed the permitted values for $\mathrm{Hg}$, defined by Slovene regulations (Ur. l. SFRJ 1987). Considering also relatively high levels of $\mathrm{Pb}$ in liver of animals shot in the control area $(0.55 \pm$ $0.13 \mathrm{mg} \mathrm{kg}^{-1}, 2.5-5$-fold higher as near the Slovenian thermal power plants of Šoštanj and Trbovlje, respectively), the possibility that animals are being exposed to contaminants that we would not have expected from other data is demonstrated. The conclusion suggests that beside single point sources, multiple dispersed sources of pollutants should also be considered as an important contribution to metal burdens in wildlife. Therefore, rather than precisely determine sources of heavy metal pollution, the use of wildlife as accumulative indicators should be aimed at detecting affected areas for the needs of performing relevant risk-assessment.
Here we do stress that only preliminary results of first sampling year are given in the paper, thus some simplifications in data interpretation were made. Especially, differences in the abiotic environment (altitude, precipitation, soil etc.) of the home range of each single animal were not taken into account. However, the areas represented here as "hot spots" have generally very similar environmental conditions (Fridl et al. 1998). They are all situated in the prealpine region with a moderately warm and moist climate (an annual rainfall between 1200 and $1600 \mathrm{~mm}$, a mean year temperature $6-10^{\circ} \mathrm{C}$ ). The predominant soil types in all the areas are acidic brown soils on silicate rock and brown soils on carbonate rock, while the potential natural vegetation belongs to the Fagetalia associations (e.g. Castaneo-Fagetum, Hacquetio-Fagetum, Ostryo-Fagetum). Thus, it is reasonable to assume that, in spite of simplifications, the levels of heavy metals found in tissue samples reflect the influence of environmental pollution on the heavy metal burdens in wildlife. 
Table 7. Levels of $\mathrm{Cd}, \mathrm{Hg}$, As and $\mathrm{Zn}$ in kidneys and $\mathrm{Pb}$ in liver of roe deer in some European countries and white-tailed deer in the North America ( $\mathrm{mg} \mathrm{kg}^{-1}$ wet weight). Arithmetic means with range in parenthesis (where available) are given.

\begin{tabular}{|c|c|c|c|c|c|c|c|c|}
\hline $\begin{array}{l}\text { State } \\
\text { (region) }\end{array}$ & Period & $\mathrm{n}$ & $\mathrm{Cd}$ & $\mathrm{Pb}$ & $\mathrm{Hg}$ & As & $\mathrm{Zn}$ & Author \\
\hline \multicolumn{9}{|l|}{ Roe deer ${ }^{a}$} \\
\hline $\begin{array}{l}\text { Slovenia } \\
\text { (Koroška region)* }\end{array}$ & 1986 & 35 & $\begin{array}{l}2.21 \\
(0.21-6.32)\end{array}$ & $\begin{array}{l}1.15 \\
(<0.05-6.34)\end{array}$ & l & l & l & Osrajnik (1990) \\
\hline $\begin{array}{l}\text { Slovenia } \\
\text { (Ilirska Bistrica) }\end{array}$ & 1986 & 14 & $\begin{array}{l}1.63^{b} \\
(0.36-4.68)\end{array}$ & $\begin{array}{l}0.44 \\
(<0.05-1.10)\end{array}$ & l & $\begin{array}{l}0.08 \\
(0.05-0.13)\end{array}$ & l & Tomšič (1986) \\
\hline $\begin{array}{l}\text { Austria } \\
\text { (Melk) }\end{array}$ & $?$ & 23 & $\begin{array}{l}2.41 \\
(0.25-9.79)\end{array}$ & i & l & i & l & Tataruch (1984) \\
\hline $\begin{array}{l}\text { Austria } \\
\text { (Achental) }\end{array}$ & $?$ & 21 & $\begin{array}{l}1.89 \\
(0.39-5.91)\end{array}$ & l & l & l & l & Tataruch (1984) \\
\hline $\begin{array}{l}\text { Germany } \\
\text { (Saarländ) }\end{array}$ & 1984 & 18 & $\begin{array}{l}1.49^{\mathrm{b}} \\
(0.31-4.18)\end{array}$ & l & l & l & $\begin{array}{l}55.5 \\
(41-74)\end{array}$ & Müller (1985) \\
\hline $\begin{array}{l}\text { Germany } \\
\text { (Tübingen) }\end{array}$ & $\begin{array}{l}1989- \\
1990\end{array}$ & $\begin{array}{l}23- \\
26\end{array}$ & $\begin{array}{l}0.99^{\mathrm{b}} \\
(0.06-3.38)\end{array}$ & $\begin{array}{l}0.08 \\
(0.02-0.41)\end{array}$ & $\begin{array}{l}0.02 \\
(0.00-0.16)\end{array}$ & l & i & $\begin{array}{r}\text { Glück and Hahn } \\
\text { (1991) }\end{array}$ \\
\hline $\begin{array}{l}\text { Poland } \\
\text { (northern Poland) }\end{array}$ & $\begin{array}{l}1987- \\
1991\end{array}$ & 75 & $\begin{array}{l}1.5^{\mathrm{b}} \\
(0.06-4.1)\end{array}$ & $\begin{array}{l}0.19 \\
(0.03-0.87)\end{array}$ & $\begin{array}{l}0.05 \\
(0.00-0.26)\end{array}$ & 1 & $\begin{array}{l}48 \\
(39-90)\end{array}$ & Falandysz (1994) \\
\hline $\begin{array}{l}\text { Poland } \\
\text { (Wielkopolska r.) }\end{array}$ & $\begin{array}{l}1987- \\
1990\end{array}$ & 120 & $\begin{array}{l}1.42^{\mathrm{b}} \\
(0.13-3.20)\end{array}$ & $\begin{array}{l}0.12 \\
(0.07-0.97)\end{array}$ & I & l & $36.2-43.7^{c}$ & c $\begin{array}{r}\text { Michalska and } \\
\text { Zmudzki (1992) }\end{array}$ \\
\hline $\begin{array}{l}\text { Slovakia } \\
\text { (West Carpathian) }\end{array}$ & 1991 & 37 & $\begin{array}{l}3.16^{\mathrm{b}} \\
(0.16-8.31)\end{array}$ & $\begin{array}{l}0.20 \\
(0.03-2.64)\end{array}$ & $\begin{array}{l}0.18 \\
(0.01-0.83)\end{array}$ & $\begin{array}{l}0.01 \\
(0.01-0.02)\end{array}$ & l & Findo et al. (1993) \\
\hline $\begin{array}{l}\text { Czech Republic } \\
\text { (different regions) }\end{array}$ & $\begin{array}{l}1986- \\
1989\end{array}$ & $\begin{array}{l}65- \\
78\end{array}$ & $\begin{array}{l}0.53 \\
(0.01-3.10)\end{array}$ & $\begin{array}{l}0.33 \\
(0.00-2.09)\end{array}$ & $\begin{array}{l}0.25 \\
(0.00-2.33)\end{array}$ & l & I & $\begin{array}{r}\text { Bukovjan et al. } \\
\text { (1991) }\end{array}$ \\
\hline $\begin{array}{l}\text { Bulgaria } \\
\text { (different regions) }\end{array}$ & $\begin{array}{l}1986- \\
1987\end{array}$ & 9 & $0.79 \pm 0.14$ & $0.85 \pm 0.16$ & I & l & $248 \pm 56.8$ & $\begin{array}{r}\text { Millanov et al. } \\
\text { (1994) }\end{array}$ \\
\hline $\begin{array}{l}\text { Lichenstein } \\
\text { (?) }\end{array}$ & $?$ & 70 & 0.77 & 0.07 & 0.05 & l & $\mathrm{T}$ & $\begin{array}{l}\text { Tataruch (1989; cit. } \\
\text { Findo et al. 1993) }\end{array}$ \\
\hline $\begin{array}{l}\text { Switzerland } \\
\text { (?) }\end{array}$ & $?$ & 67 & 0.87 & 0.06 & 0.06 & l & $\mathrm{T}$ & $\begin{array}{l}\text { Tataruch (1990; cit. } \\
\text { Findo et al. 1993) }\end{array}$ \\
\hline $\begin{array}{l}\text { Norway } \\
\text { (different regions) }\end{array}$ & $\begin{array}{l}1983- \\
1984\end{array}$ & $\begin{array}{l}73- \\
77\end{array}$ & $\begin{array}{l}2.8^{\mathrm{b}} \\
(0.2-14.0)\end{array}$ & l & l & l & l & Froslie et al. (1986) \\
\hline $\begin{array}{l}\text { Sweden } \\
\text { (different regions) }\end{array}$ & $\begin{array}{l}1973- \\
1976\end{array}$ & 25 & $\begin{array}{l}5.2^{\mathrm{d}} \\
(0.07-8.6)\end{array}$ & l & l & l & l & Frank (1986) \\
\hline \multicolumn{9}{|l|}{ White-tailed deer ${ }^{\text {a }}$} \\
\hline $\begin{array}{l}\text { Oklahoma } \\
\text { (different regions) }\end{array}$ & $?$ & 64 & $6.97^{b}$ & l & 0.18 & 0.19 & l & Kocan et al. (1980) \\
\hline $\begin{array}{l}\text { Illinois }{ }^{\mathrm{e}} \\
\text { (different regions) }\end{array}$ & 1980 & 190 & l & $\begin{array}{l}1.16 \\
(0.00-3.71)\end{array}$ & l & l & l & Woolf et al. (1982) \\
\hline $\begin{array}{l}\text { Pennsylvania }{ }^{\mathrm{e}, \mathrm{f}} \\
\text { (Palmerton area) }^{*}\end{array}$ & $\begin{array}{l}1980- \\
1981\end{array}$ & 23 & $\begin{array}{l}4.43-26.8^{g} \\
(0.88-114)\end{array}$ & $\begin{array}{l}0.06-0.23^{\mathrm{g}} \\
(0.03-0.51)\end{array}$ & l & l & $\begin{array}{l}41.4-88.6^{g} \\
(29.4-130)\end{array}$ & $\begin{array}{r}\text { g } \quad \text { Sileo and Beyer } \\
(1985)\end{array}$ \\
\hline $\begin{array}{l}\text { Quebec } \\
\text { (different regions) }\end{array}$ & 1985 & 125 & $5.97-11.1^{h}$ & i & l & l & i & Crete et al. (1987) \\
\hline $\begin{array}{l}\text { Connecticut }{ }^{\mathrm{e}} \\
\text { (different regions) }\end{array}$ & $\begin{array}{l}1990- \\
1992\end{array}$ & 8 & 4.69 & l & l & l & $\mathrm{Mu}$ & lusante et al. (1993) \\
\hline
\end{tabular}

Notes:

* Research was performed in the vicinity of local emission source (lead smelter in Slovenia, zinc smelter in Pennsylvania).

${ }^{a} \mathrm{Cd}, \mathrm{Hg}, \mathrm{As}, \mathrm{Zn}$ levels in kidneys and $\mathrm{Pb}$ levels in liver are given only due to comparability with our research.

${ }^{\mathrm{b}}$ Age of animals was not considered, thus the Cd levels could not been directly compared with values given in Table 1 .

${ }^{\mathrm{c}} \mathrm{Zn}$ levels between spring and autumn period were different.

${ }^{\mathrm{d}}$ Median is presented instead of arithmetic mean.

${ }^{\mathrm{e}}$ Converted from dry weight (wet weight = dry weight / 3.5; see Cooke and Johnson 1996).

${ }^{\mathrm{f}}$ Geometric means are presented instead of arithmetic means.

$\mathrm{g}$ Levels of heavy metals significantly decreased with distance from the zinc smelter, thus geometric means in different distances from the smelter are presented.

${ }^{\mathrm{h}}$ The Cd levels were different among areas. 
Beside the comparison among Slovenian regions, a collation with some other countries could be interesting as well. A review of some previous research papers concerned with heavy metal levels in viscera of European roe deer and North-American white-tailed deer (both species have rather similar ecological niches) is presented in Table 7 . To make those results comparable with our study, only $\mathrm{Cd}$, $\mathrm{Hg}$, As and $\mathrm{Zn}$ levels in kidneys and $\mathrm{Pb}$ levels in liver are given. It should be stressed that comparison among studies should be made with a caution due to different environmental conditions as well as due to some discrepancies in methodology (e.g. different seasons of deer hunting, (non)consideration of animal's age in processing of data, (non)elimination of secondary contamination by lead bullets, need for recalculation from dry weight basis in some studies). Nevertheless, it seems that the levels of $\mathrm{Hg}$, As, $\mathrm{Zn}$ and $\mathrm{Pb}$ in roe deer tissues from Slovenian regions generally do not differ (they are in the same order of magnitude) from data obtained in previous studies. On the contrary, Cd levels in kidneys of roe deer shot in the vicinity of Slovenian metallurgical and electricity generating centres are noticeably higher in comparison with levels obtained in previous studies. At least three reasons should be considered: a) temporal remoteness of studies, b) (non)consideration of animal's age in processing of data and c) choice of sampling area in a spatial sense.

Firstly, the majority of cited studies were performed in 1980s. Since the Cd burdens have significantly increased in the last decade (as it is shown by temporal comparison for the Koroška region), the comparison among studies made in different periods could be misleading. Secondly, age was not taken into account in data interpretation in the majority of cited studies (see Table 7), therefore the $\mathrm{Cd}$ levels could not be directly compared with our research. That discrepancy can certainly be an important reason for high levels of Cd, obtained in our study. If we pooled together data for all age classes, the mean levels of Cd in kidneys would be $5.30 \mathrm{mg} \mathrm{kg}^{-1}, 15.2 \mathrm{mg} \mathrm{kg}^{-1}, 7.8 \mathrm{mg} \mathrm{kg}^{-1}$ and $3.17 \mathrm{mg} \mathrm{kg}^{-1}$ of a wet weight in the Šalek Valley, the Koroška region, the Zasavje region and the Pokljuka Plateau, respectively. Except the Koroška region, those levels are comparable with other studies. Finally, the bioindicative approach was emphasised in our research project, thus sampling areas were chosen in the vicinity of local pollution sources. On the contrary, in many of cited studies the sanitary approach (establishing the edibility of game organs) was stressed, therefore wide-ranged areas were investigated. From that point of view, the study performed near the zinc smelter in Pennsylvania (Sileo and Beyer 1985) is comparable with our work in the Koroška region. In both regions, levels of $\mathrm{Cd}$ in deer kidneys are extremely high and decline with the distance from the smelter. In the case of the Koro?ka region, those levels decrease by $20 \%$ in the distance between 10 and $13.5 \mathrm{~km}$ (considering the site where each animal was shot) relative to the decrease over the first $10 \mathrm{~km}$ (Pokorny and Ribari?-Lasnik 2000). The decline is even more evident for $\mathrm{Pb}$; its levels in liver decrease by $80 \%$ in the distance between 5 and 9.9 , km relative to its decline up to a distance of $4.9 \mathrm{~km}$ (ibid).

The influence of distance from local emission sources on the heavy metal levels in soft tissues of roe deer, together with spatial and temporal comparisons given in the paper, confirm the bioindicative value of the species. Due to its choice of fodder (its favoured food often contains more heavy metals than other plants at the same location; Müller 1985), roe deer generally accumulate more toxic elements (especially $\mathrm{Cd}$ and $\mathrm{Hg}$ ) than other wild ungulates found in central Europe (see Tataruch 1991, Michalska and Zmudzki 1992, Findo et al. 1993 for comparison with red deer; Pokorny 1999b for fallow deer Dama dama, Tataruch 1991 for chamois Rupicapra rupicapra). Therefore, of central European ungulates, roe deer is probably the best bioindicator of heavy metal burdens of the environment. Since it is also the most numerical and consequently the most important big-game for the higher links of food-web (including humans), the analyses of heavy metal levels in roe deer tissues have also other benefits, such as environmental and human risk assessment. Because animal tissue levels of heavy metals can provide important data regarding the fate and bioavailability of contaminants within natural ecosystems (Wren 1986), survey of residues in wildlife tissues (together with monitoring various physical, chemical and biological compartments of an ecosystem) is important from the bioindicative and conservation, as well as anthropocentric point of view.

Acknowledgements - The research was financially supported by the Šoštanj Thermal Power Plant and The Ministry of Science and Technology of the Republic of Slovenia. Simona Diklič and Milica Kač helped us with the translation. Finally, we owe a deep debt of gratitude to all those who helped with the collection of samples.

\section{References}

Åberg, G. et al. 1999. The origin of atmospheric lead in Oslo, Norway, studied with the use of isotophic ratios. - Atmosph. Environ. 33: 3335-3344.

Anon. 1987. Pravilnik o količinah pesticidov in drugih strupenih snovi, hormonov, antibiotikov in mikotoksinov, ki smejo biti v živilih. - Ur. l. SFRJ 79: 1842-1846, in Slovene.

Arndt, U., Nobel, W. and Schweizer, B. 1987. Bioindikatoren: Möglichkeiten, Grenzen und neue Erkenntnisse. - Ulmer, Stuttgart.

Bukovjan, K., Pav, J. and Karpenko, A. 1991. Determination of residual of chemical elements in organs and muscles of roe deer. - Folia Venatoria 21: 67-76, in Czech with English summary.

Chudik, I. and Mankovska, B. 1990. Accumulation of selected elements in organs and fur of game. - Vedecké práce (Zvolen) 39: 265-277, in Slovak with English summary. 
Chyla, A. et. al. 1996. Pollution effects on wildlife: roe deer antlers as non-destructive bioindicator. - Environ. Protect. Engin. 22: 65-70.

Cooke, J. A. and Johnson, M. S. 1996. Cadmium in small mammals. - In: Beyer, W. N., Heinz, G. H. and Redmon-Norwood, A. W. (eds), Environmental contaminants in wildlife. Lewis publishers, New York, pp. 377-388.

Crete, M. et al. 1987. Pattern of cadmium contamination in the liver and kidneys of moose and white-tailed deer in Quebec. - Sci. Total Environ. 66: 45-53.

Doganoc, D. Z. and Šinigoj-Gačnik, K. 1995. Lead and cadmium in meat and organs of game in Slovenia. - Bull. Environ. Contam. Toxicol. 54: 166-170.

Falandysz, J. 1994. Some toxic and trace metals in big game hunted in the northern part of Poland in 1987-1991. - Sci. Total Environ. 141: 59-73.

Findo, S. et al. 1993. Akkumulation von ausgewählten Schwermetallen beim Rot- und Rehwild im zentralen Teil der Westkarpaten (Mittelslowakei). - Z. Jagdwiss. 39: 181-189.

Frank, A. 1986. In search of biomonitors for cadmium: cadmium content of wild Swedish fauna during 1973-1976. - Sci. Total Environ. 57: 57-65.

Froslie, A. et al. 1986. Levels of cadmium in liver and kidneys from Norwegian cervides. - Bull. Environ. Contam. Toxicol. 37: 453-460.

Fridl, J. et al. 1998. Geografski atlas Slovenije. - DZS, Ljubljana, in Slovene.

Glück, B. and Hahn, J. 1991. Schadstoffbelastung von Wild. Fleischwirtsch 71: 160-168.

Gnamuš, A. and Horvat, M. 1999. Mercury in terrestrial food webs of the Idrija mining area. - In: Ebinghaus, R. (ed.), Mercury contaminated sites: characterization, risk assessment and remediation. Springer, pp. 281-320.

Grčman, H. et al. 1999. Cadmium, lead and zinc content in soil and some vegetables near the landfill of lead smelter Mežica after accidental fire. - In: Wenzel, W. et al. (eds), Biogeochemistry of trace elements. Proc. of extended abstracts, Vienna, pp. 958-959.

Grodzinska, K., Grodzinski, W. and Zeveloff, S. I. 1983. Contamination of roe deer forage in a polluted forest of southern Poland. - Environ. Pollut. (Ser. A) 30: 257-274.

Hecht, H., Schinner, W. and Kreuzer, W. 1984. Endogene und eksogene Einflusse auf die Gehalte an Blei und Cadmium in Muskel und Organoproben von Rehwild. - Fleischwirtschaft 64: 967-969.

Hewison, A. J. M. et al. 1999. Tests of estimation of age from tooth wear on roe deer of known age: variation within and among populations. - Can. J. Zool. 77: 58-67.

Kardell, L. and Källman, S. 1985. Heavy metals in antlers of roe deer from two Swedish forests, 1968-1983. - Ambio 15: 232-235.

Kocan, A. A. et al. 1980. Heavy metal concentrations in the kidneys of white-tailed deer in Oklahoma. - J. Wildl. Diseas 16: 593-596.

Kotar, M. 1977. Statistične metode - izbrana poglavja za študij gozdarstva. - Biotehniška fakulteta, Ljubljana, in Slovene.

Ma, W. 1996. Lead in mammals. - In: Beyer, W. N., Heinz. G. H. and Redmon-Norwood, A. W. (eds), Environmental contaminants in wildlife. Lewis Publishers, New York, pp. 281296.
Mankovska, B. 1980. The concentration of four toxic elements in the teeth of roe deer from the area of an aluminium plant. - Biologia (Bratislava) 35: 819-822.

Michalska, K. and Žmudzki, J. 1992. Metal concentrations in wild pig, roe and deer tissues of the Wielkopolska region. Medycyna Wet. 48: 160-162, in Polish with English summary

Millanov, Z. et al. 1994. Concentrations of heavy metals in inner organs and meat of certain resource species of big game. Nauka za gorata 2: 72-78, in Bulgarian with English summary.

Musante, C. L., Ellingwood, M. R. and Stilwell, D. E. 1993. Cadmium contamination in deer livers in Connenticut. Bull. Environ. Contam. Toxicol. 51: 838-843.

Müller, P. 1985. Cadmium-Konzentrationen bei Rehpopulationen (Capreolus capreolus) und deren Futterpflanzen. - Z. Jagdwiss. 31: 146-153.

Niemi, A. et al. 1993. Heavy metals in muscle, liver and kidney from Finnish elk in 1980-81 and 1990. - Bull. Environ. Contam. Toxicol. 50: 834-841.

Osrajnik, E. 1990. Svinec in kadmij v mesu in organih divjadi na območju Koroške. - Magistrsko delo, Veterinarska fakulteta, Ljubljana, in Slovene.

Pascoe, G. A., Blanchet, R. J. and Linder, G. 1996. Food chain analysis of exposures and risks to wildlife at a metal-contaminated wetland. - Arch. Environ. Contam. Toxicol. 30: 306318.

Pokorny, B. 1999a. Raziskava onesnaženosti notranjih organov prostoživečih živali $s$ težkimi kovinami $\mathrm{v}$ emisijsko ogroženih predelih Slovenije (v Šaleški dolini, Zasavju in na Koro?kem). - ERICo Velenje, DP-421/99, in Slovene.

Pokorny, B. 1999b. Evaluation of fallow deer (Dama dama) presence in the Velenje coal-mine subsidence area. - Zb. Gozd. Lesar. 60: 53-83, in Slovene with English summary.

Pokorny, B. and Ribarič-Lasnik, C. 2000. Lead, cadmium and zinc in tissues of roe deer (Capreolus capreolus) near the lead smelter in the Koroška region (northern Slovenia). - Bull. Environ. Contam. Toxicol. 64: 20-26.

Ribarič-Lasnik, C. et al. 1999. Change in the condition of Norway spruce forest after the installation of desulphurization devices at the Šoštanj Thermal Power Plant. - J. Forest Sci. 45: 217-222.

Samiullah, Y. and Jones, K. C. 1991. Deer antlers as pollution monitors in the United Kingdom. - In: Bobek, B., Perzanowski, K. and Regelin, W. (eds), Global trends in wildlife management. Trans. 18th IUGB Congress, Swiat Press, Krakow, pp. 415-420.

Sawicka-Kapusta, K. 1979. Roe deer antlers as bioindicators of environmental pollution in southern Poland. - Environ. Pollut. 19: 283-329.

Sileo, L. and Beyer, W. N. 1985. Heavy metals in white-tailed deer living near a zinc smelter in Pennsylvania. - J. Wildl. Diseas 21: 289-296.

Simonič, A. 1976. Srnjad - biologija in gospodarjenje. Zlatorogova knjižnica, Lovska zveza Slovenije, Ljubljana, in Slovene.

Straub, H. P. and Kreimes, K. 1995. Rehe als Akkumulationsindikatoren. - In: Umlauff-Zimmermann, R. (ed.), Methoden zu Wirkungserhebungen. Landensanstalt für Umweltschultz, Karlsruhe, pp. 52-54. 
Stropnik, B. et al. 1994. Air pollution monitoring in the Šalek Valley. - Acta Chimica Slovenica 41: 65-82.

Swiergosz, R. et al. 1993. The incidence of heavy metals and other toxic elements in big game tissues. - Sci. Total Environ. 1: 225-231.

Tataruch, F. 1984. Die Cadmium-Kontamination der Wildtiere. - Allg. Forstzeit. 21:528-530.

Tataruch, F. 1991. Freilebende Wildtiere als Bioindikatoren der Schwermetallkontamination. - VDI Berichte 901: 925936.

Tomšič, E. 1986. Rezidua svinca, kadmija in arzena v organih srnjadi, jelenjadi in divjih prašičev na širšem območju občine Ilirska Bistrica. - Magistrsko delo, Veterinarska fakulteta, Ljubljana, in Slovene.
Wittig, R. 1993. General aspects of biomonitoring heavy metals by plants. - In: Markert, B. (ed.), Plants as biomonitors indicators for heavy metals in the terrestrial environment. VCH, Weinheim, pp. 3-27.

Woolf, A., Smith, J. R. and Small, L. 1982. Metals in livers of white-tailed deer in Illinois. - Bull. Environ. Contam. Toxicol. 28: 189-194.

Wren, C. D. 1986. Mammals as biological monitors of environmental metal levels. - Environ. Monitor. Assess. 6: 127-144.

Zadnik, T. and Jazbec, I. 1996. Lead concentration in blood of dairy cows as an indicator of environmental contamination. - Zb. Vet. Fak. Univ. Ljubljana 33: 233-240. 